\title{
STRAGTEGI KOMUNIKASI PARIWISATA TAMAN AIR MANCUR SRI BADUGA MELALUI MEDIA INSTAGRAM @URANGPURWAKARTA
}

\author{
Gheya Madinatu Sjaida \\ Universitas Padjadjaran \\ Email: ghyeamsm@gmail.com \\ Ute Lies Siti Khadijah \\ Universitas Padjadjaran \\ Email: ute.lies@unpad.ac.id \\ Evie Novianti \\ Universitas Padjadjaran \\ Email: evi.novianti@unpad.ac.id
}

\begin{abstract}
Indonesian tourism was ranked 40th out of 140 countries in the world in the category of Travel and Tourism Competitiveness Index (TTCI) in 2019. This was of course supported by the advancement of regional tourism in Indonesia. One of the areas which is improving the tourism sector is Purwakarta Regency. Purwakarta Regency donates its favorite tourist destination, the Sri Baduga Situ Buleud Fountain Park which is the Top Five Tourism Destination in Indonesia. The media of his young people also helped to promote massive things related to the Sri Baduga Fountain Park. The media is named @urangpurwakarta. This research uses descriptive qualitative method with the concept of communication strategy. This research involved 3 key informants. The results of this research are the planning of @uranagpurwakarta in the form of determining targets, media and content, the implementation phase of @urangpurwakarta making Explore Purwakarta content, Purwakarta Original, Purwakarta Muda, and What the Facts Purwakarta. The evaluation phase of @urangpurwakarta becomes more active in providing information according to the direction of the organizer of Sri Baduga Water Park.
\end{abstract}

Keywords: Communication Strategy, Tourism, Instagram, Purwakarta 
Stragtegi Komunikasi Pariwisata Taman Air Mancur Sri Baduga melalui Media Instagram...

\section{Pendahuluan}

Dewasa ini, wisata telah menjadi salah satu hal yang semakin dibutuhkan di dalam kehidupan. Mengingat bahwa padatnya aktivitas sehari-hari yang seperti tidak ada habisnya baik itu karena pekerjaan ataupun kegiatan lainnya yang memang sudah terjadwalkan. Tentunya, dengan melihat hal tersebut maka kebutuhan akan menyegarkan diri perlu dilakukan. Kondisi inilah yang membuat banyak daerah di wilayah di Indonesia senantiasa berbenah guna meningkatkan kualitas pariwisatanya. Pembenahan ini membawa Indonesia ke posisi 40 besar dari 140 negara di dunia dalam kategori Travel and Tourism Competitiveness Index (TTCI) pada tahun 2019. Sebuah prestasi yang membanggakan mengingat kekayaan alam yang ada di Indonesia sangat melimpah (Desrianto, 2019).

Setiap daerah ditantang untuk menunjukan hasil pembangunannya masingmasing, terutama dalam sector pariwisata. Demikian halnya dengan pemerintah Kabupaten Purwakarta yang semakin giat dalam membangun destinasi wisata. Bahkan dalam hal ini, Pemerintah Daerah Kabupaten Purwakarta berkolaborasi dengan Pemuda Purwakarta yang memiliki ketertarikan dan kecintaan terhadap Kabupaten Purwakarta untuk senantiasa meningkatkan promosi dan juga melakukan kegiatan-kegiatan yang mampu menarik wisatawan untuk berkunjung ke Purwakarta.

Salah satu caranya yaitu bekerja sama dengan media anak muda yang diprakarsai oleh alumni SMA Negeri 1 Purwakarta, Alpiadi Prawiraningrat, yaitu @urangpurwakarta. Media anak muda ini telah berdiri sejak 2015 lalu dengan fokus di media Instagram. Konten yang dibuat oleh Alpiadi dan kawan-kawan ini bersifat edukatif dan informatif yang dikemas dengan gaya Bahasa kekinian yang bisa merangkul generasi muda untuk mau mengikuti dan membaca setiap konten yang diunggah. 
Hal ini dilakukan karena melihat bahwa adanya pergeseran media yang digunakan untuk melakukan promosi. Mengingat bahwa perkembangan teknologi di era 4.0 ini sangat pesat dan mampu mempermudah masyarakat dalam berbagai urusan. Baik itu pekerjaan, pengembangan usaha, pendidikan, bahkan promosi. Dengan melihat hal ini tentunya muncul strategi-strategi baru dalam upaya pengembangan destinasi pariwisata di setiap daerah, termasuk di Kabupaten Purwakarta. Pemanfaatan media sosial sangat penting karena kita mampu melihat sejauhmana engagement yang didapatkan dari setiap konten yang diunggah.

@urangpurwakarta ini bertajuk "Media anak muda yang mengajak untuk mempromosikan potensi pariwisata, industry produk local, serta informasi menarik tentang Purwakarta." Dengan fokus pada platform Instagram @urangpurwakarta informasi yang disajikan pun beragam dan menarik seperti destinasi wisata, gerai kuliner, ataupun event yang akan berlangsung di Kabupaten Purwakarta.

Kabupaten Purwakarta merupakan salah satu kabupaten yang terletak di Jawa Barat. Posisinya yang berada di jalur menuju Bandung ini kerap kali dijadikan destinasi wisata alternative oleh para wisatawan yang hendak ke Bandung atau sekedar mampir untuk menyantap makanan khas Purwakarta yaitu Sate Maranggi. Destinasi wisata yang dimiliki oleh Purwakarta sebenarnya tidak kalah dibandingkan dengan destinasi wisata daerah lain. Hanya saja, promosi yang dilakukan cenderung tidak massif pada saat itu. Promosi destinasi wisata Purwkarta mulai gencar pada saat dan pasca peresmian Taman Air Mancur Sri Baduga Situ Buleud yang merupakan air mancur terbesar se-Asia Tenggara pada tahun 2017. Taman Air Mancur Sri Baduga ini berada di lahan Situ Buleud dengan luas 2 hektar (Nugraha, 2018). Pasca peresmiannya, Taman Air Mancur Sri Baduga Situ Buleud ini tidak pernah sepi pengunjung, terutama pada waktu pertunjukannya di akhir pekan. Dengan adanya perkembangan teknologi informasi dan juga pemberitaan yang ada di media online, 
destinasi pariwisata yang ada di Purwakarta saat ini sudah mulai banyak diketahui oleh masyarakat ramai.

“Taman Air Mancur Sri Baduga pada Tahun 2015 sudah mulai beroperasi dan akhirnya rame pengunjung yang datang ke Purwakarta. Muncul deh pemberitaan dari media, terutama di medsos (media sosial) yang mempublikasikan air mancur yang terbesar dan bagus untuk dikunjungi dan akhirnya dijadikanlah destinasi unggulan yang ada di Purwakarta" (Irfan, 2020).

Penyebaran infromasi yang mudah dan cepat melalui media sosial Instagram, @urangpurwakarta senantiasa menonjolkan sisi baik dan positif yang ada di Purwakarta. Sehingga menjadikan akun ini sebagai akun rekomendasi dengan tingkat aktivasi dan juga pengelolaan yang baik. Saat ini, jumlah pengikut akun @urangpurwakarta sendiri telah mencapai 40.200 pengikut dengan jumlah postingan sebesar 850. ${ }^{1}$ Melihat jumlah pengikut pada akun @urangpurwakarta tersebut menjadikan sebuah indikator bahwa akun ini dapat dipercaya. Informasi yang disajikan pun menarik, terutama banyaknya postingan terkait dengan Taman Air Mancur Sri Baduga Situ Buleud Purwakarta.

Informasi yang disajikan oleh akun@urangpurwakarta ini tidak hanya berupa lokasi dan juga sekedar gambar menarik sebagai konten utama mereka, melainkan juga informasi seputar jadwal pertunjukan Air Mancur Sri Baduga. Mengingat bahwa debit air yang memang hanya mengandalkan sumber mata air Situ Buleud itu sendiri, menjadikan jadwal pertunjukan Taman Air Mancur Sri Baduga ini tidak tentu terutama pada saat musim kemarau. Hal ini sangat penting bagi wisatawan yang ingin berkunjung sehingga tidak ada lagi missed communication antara pihak penyedia wisata dan juga pengunjung.

${ }^{1}$ Media Sosial Instagram @urangpurwakarta, diakses pada 4 Juli 2020. 
Tentunya, strategi komunikasi yang dilakukan oleh @urangpurwakarta diselaraskan dengan arahan dari Pemerintah Daerah Kabupaten Purwakarta melalui Bidang Pariwisata. Penyelarasan ini dilakukan mengingat fokus utama @urangpurwakarta sebagai media anak muda yang mengajak untuk mempromosikan pariwisata, gerai kuliner dan informasi menarik tentang Purwakarta yang harus berisikan informasi sesuai dengan data dan arahan yang disampaikan oleh Pemerintah Daerah Kabupaten Purwakarta.

\section{Metode Penelitian}

Metode yang digunakan dalam penulisan ini adalah deskriptif dengan pendekatan kualitatif. Menurut Usman penelitian dengan menggunakan metode deskriptif bermaksud membuat penyandaraan secara sistematis, faktual, dan akurat mengenai fakta-fakta dan sifat-sifat populasi tertentu (Usman, 2009). Sedangkan menurut Nawawi, penelitian deskriptif merupakan prosedur pemecahan masalah yang diselidiki dengan menggambarkan atau melukiskan keadaan subjek atau objek penelitian berdasarkan fakta yang tampak sebagaimana adanya (Hadari, 2003).

Bob dan Taylor, mendefinisikan pendekatan kualitatif adalah prosedur penelitian yang menghasilkan data deskriptif berupa kata-kata tertulis atau lisan dari orang-orang dan perilaku yang dapat diamati (Moleong, 2005). Penelitian kualitatif adalah penelitian untuk menjawab permasalahan yang memerlukan pemahaman secara mendalam dalam konteks waktu dan situasi yang bersangkutan, dilakukan secara wajar dan alami sesuai dengan kondisi objektif di lapangan tanpa adanya manipulasi, serta jenis data yang dikumpulkan terutama data kualitatif (Arifin, 2012).

Menurut Littlemore, dalam The Communicative Effectiveness of Diferent Types of Communication Strategy menjelaskan bahwa strategi komunikasi merupakan Langkahlangkah yang harus diambil di dalam meningkatkan efektifitas komunikasi (Littlemore, 2003). Strategi komunikasi juga didefinisikan oleh Effendi sebagai 
panduan dari perencanaan komunikasi (Communication Planning) dan manajemen komunikasi (Communication Management) untuk mencapai suatu tujuan (Effendy, 1993). Strategi komunikasi ini harus dapat menunjukan operasional secara taktis harus dilakukan. Dalam arti kata bahwa pendekatan bisa berbeda sewaktu-waktu bergantung pada situasi dan kondisi agar tujuan tetap dapat tercapai. Berdasarkan definisi tersebut dapat kita simpulkan bahwa strategi komunikasi merupakan Langkah perencanaan dan pengelolaan yang diambil untuk mencapai suatu tujuan bersama.

Media sosial saat ini telah menggeser kecenderungan konsumsi pariwisata, jika dahulu pariwisata bukan hal utama dalam urutan prioritas, namun dengan adanya kemudahan dalam mengakses informasi dan potensi wisata yang ada di suatu daerah, menimbulkan keinginan masyarakat untuk bertandang dan melihat langsung lokasi wisata tersebut. Belum lagi trend mengisi laman media sosial dengan konten foto dan video sebagai ajang unjuk ekspresi dan eksistensi, hal tersebut inilah yang menjadi faktor pendorong masyarakat untuk mulai memasukan pariwisata dalam daftar prioritas kehidupannya.

Promosi pariwisata melalui media sosial dapat diartikan sebagai cara yang tergolong baru yang memiliki dampak besar dalam mendorong mobilitas wisatawan (Fatanti \& Suyadnya, 2015). Penggunaan media sosial menjadikan wisatawan atau konsumen dengan mudah membagikan pengalaman serta dapat digunakan sebagai sumber dalam melakukan pencarian informasi mengenai destinasi wisata yang diinginkan (Gohil, 2015).

Penelitian ini dilakukan di Kabupaten Purwakarta dengan melakukan wawancara mendalam dengan beberapa informan yang dianggap memenuhi kompetensi menurut peneliti. Informan dalam penelitian ini terdiri dari Alpiadi Prawiraningrat selaku pendiri dari @urangpurwakarta, Muhammad Rifki selaku 
Kepala Tim Program and Event @urangpurwakarta, serta Bapak Irfan selaku Kepala Bidang Pariwisata Dinas Pendidikan, Pemuda, Olahraga, Budaya dan Pariwisata.

\section{Hasil dan Pembahasan}

Sebelum menjadi Taman Sri Baduga, taman ini adalah danau yg cukup luas berbentuk bulat yg disebut Situ Buleud. Asal usul Situ Buleud berkaitan dengan peristiwa perpindahan ibukota Kabupaten Karawang dari Wanayasa ke Sindangkasih, tepatnya sejalan dengan pembangunan infrastruktur kota Purwakarta pada tahap awal. Situ Buleud dibuat atas gagasan Bupati R.A. Suriawinata. Pembuatannya berlangsung antara tahun 1830 - pertengahan tahun 1831 (Purwakarta, 2018).

Situ Buleud dibuat dengan dua tujuan dan kegunaan. Pertama sebagai sumber air bagi kepentingan Pemerintah dan masyarakat kota Purwakarta. Air dari situ antara lain digunakan untuk keperluan ibadah dan kegiatan lain di Masjid Agung. Kedua sebagai tempat rekreasi. Untuk kepentingan kegunaan atau tujuan kedua, ditengah situ didirikan bangunan tradisional sejenis bangunan gazebo (bangunan tanpa dinding) sebagai tempat istirahat (pasanggrahan). Pembagunan Situ Buleud dengan tujuan atau kegunaan kedua, boleh jadi berkaitan erat dengan salah satu hak istimewa Bupati, yaitu hak untuk menangkap ikan di sungai atau danau. Hak istimewa itu merupakan bagian dari gaya hidup bupati waktu itu. Dalam kenyataannya, yang menangkap ikan bukan Bupati, melainkan sejumlah rakyat. Dalam acara itu, Bupati tinggal di pasanggrahan yang berada di tengah situ menyaksikan sejumlah rakyat menangkap ikan. Acara itu biasanya dimeriahkan oleh iringan gamelan(Purwakarta, 2018).

Taman Air Mancur Sri Baduga Situ Buleud merupakan wisata yang baru diresmikan pada tanggal 6 Januari 2017 oleh Menteri Pariwisata Arief Yahya bersama Bupati Purwakarta H. Dedi Mulyadi. Wisata ini memiliki luas lebih dari dua hektar 
yang menyuguhkan pertunjukan air mancur dengan menggunakan tekhnologi canggih dan unsur seni. Taman Air Mancur Sri Baduga Situ Buleud menjunjung tinggi nilai kebudayaan. Taman Air Mancur Sri Baduga Situ Buleud mencerminkan budaya Sunda dan Bhineka Tunggal Ika. Bhineka Tunggal Ika tercerminkan dari warna warni air mancur tersebut. Wisata ini mengangkat Prabu Siliwangi yang biasa disebut Sri Baduga Maharaja sebagai ikon air mancur tersebut, karena Prabu Siliwangi merupakan seorang raja yang berasal dari tanah Sunda yang membangun kepemimpinannya melalui nilai kasih sayang.

Dengan melihat potensi wisata baru yang ada di Purwakarta, anak-anak muda Purwakarta yang diinisiasi oleh Alpiadi Prawiraningrat kemudian membentuk sebuah tim publikasi yang berisikan informasi menarik seputar Purwakarta, pariwisata Purwakarta, dan juga gerai kuliner khas Purwakarta. Publikasi tersebut dilakukan melalui media sosial Intagram dengan akun @urangpurwakarta yang didirikan pada tahun 2015. Dengan adanya Taman Air Mancur Sri Baduga Situ Buleud ini tentunya menambah kebanggan tersendiri untuk masyarakat Purwakarta karena keindahan dan kemegahan Taman Air Mancur Sri Baduga ini mampu menarik minat wisatawan lokal maupun mancanegara untuk mengunjungi Purwakarta. Hal tersebut pula lah yang menjadi pecutan semangat tim @urangpurwakarta untuk terus memberikan konten menarik seputar Purwakarta, terutama informasi mengenai Taman Air Mancur Sri Baduga Situ Buleud.

\section{Strategi Komunikasi @urangpurwakarta}

\section{Perencanaan}

Seperti yang disampaikan oleh Littlemore (2003) dan Effendy (1993) bahwa perencanaan adalah salah satu tahap penting dalam sebuah strategi komunikasi. Dalam tahap awal ini, tim dari @urangpurwakarta ini menentukan media sosial apa yang akan digunakan untuk menyampaikan informasi mengenai wisata Purwakarta, 
gerai kuliner Purwakarta dan juga informasi menarik lainnya tentang Purwakarta. Pemilihan media sosial ini tentunya akan menjadi sebuah medium indikator keberhasilan sebuah promosi dalam hal ini wisata Taman Air Mancur Sri Baduga. Hingga akhirnya tim @urangpurwakarta memilih media sosial Instagram sebagai media mereka menyebarkan informasi.

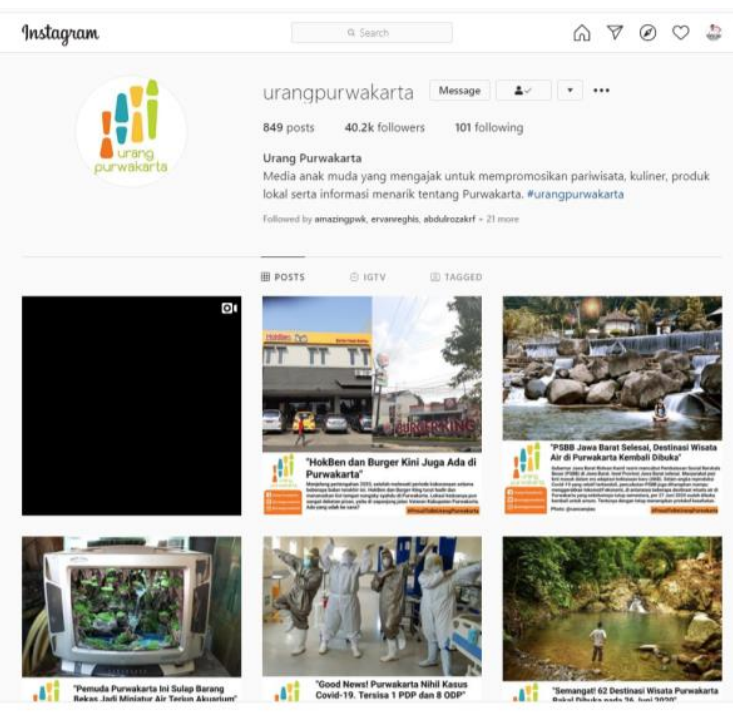

Gambar 1. Laman Profil Instagram @urangpurwakarta

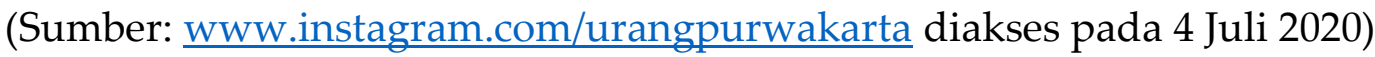

Alasan memilih Instagram sebagai media berbagi karena Instagram adalah media sosial yang dekat dengan kaum milenial yang selalu berisikan konten-konten terkini. Penentuan target audiens sudah sangat jelas bahwa @urangpurwakarta ingin merangkul anak-anak muda kaum milenial untuk cinta terhadap kotanya, yaitu Purwakarta dan pemilihan Instagram menjadi sebuah pilihan tepat jika ingin menyampaikan informasi kepada anak muda yang ada di Purwakarta. Target utama dari@urangpurwakarta merupakan anak-anak muda (Purwakarta khususnya) dengan rentang usia belasan tahun sampai 30 tahunan. 
“Jadi kan target utama dari sosial media Urang Purwakarta ini adalah anak muda dan kita melihat kalau misalnya kebanyakan anak muda itu yang menggunakan Instagram untuk aktivitas bersosial medianya makanya kita lihat kalau misal Instagram ini menjadi alat yang tepat kalau misalnya kita ingin menyebarkan informasi tentang Purwakarta ke anak mudanya"(Prawiraningrat, 2020).

Taman Air Mancur Sri Baduga yang dibangun dengan penuh keindahan dan kemegahan ini bisa dijadikan objek berswafoto bagi siapapun terutama generasi muda yang memang menyukai kegiatan foto-foto. Banyak sekali titik - titik tempat yang bisa dijadikan sebagai objek foto maupun latar belakang foto. Hal ini lah yang kemudian masuk dalam perencanaan pembuatan konten media Instagram @urangpurwakarta guna menarik lebih banyak pengikut dan meningkatkan engagement di Instagram itu sendiri.

Dalam tahap perencanaan ini pun konten-konten terkait dengan promosi Taman Air Mancur Sri Baduga tidak hanya berfokus pada foto keindahan saja. Tim dari @urangpurwakarta mengumpulkan banyak data dan fakta menarik tentang Taman Air Mancur Sri Baduga dan Situ Buleudnya itu sendiri. Selain dari konten media sosial, tim @urangpurwakarta pun Menyusun beberapa kegiatan menarik lainnya yang berhubungan dengan Taman Air Mancur Sri Baduga, dengan tujuan untuk meningkatkan jumlah kunjungan dan bagaimana respon dari pengikut di Instagram@urangpurwakarta terkait dengan kegiatan yang akan dilaksanakan di Taman Air Mancur Sri Baduga. 
Tabel 1. Tahap Perencanaan Strategi Komunikasi Pariwisata @urangpurwakarta

\begin{tabular}{|l|l|ll|}
\hline No & Perencanaan & \\
\hline 1 & Target & - Anak Muda (Usia 15-30 Tahun) \\
& & $\begin{array}{l}\text { - } \\
\text { - }\end{array}$ & - Menggunakan Media Sosial Instagram \\
& & - Tertarik dengan Wisata dan Kuliner \\
\hline 2 & Konten & $\begin{array}{l}\text { - Informasi Unik } \\
\end{array}$ & - Event \\
\hline
\end{tabular}

\section{Pelaksanaan}

Tahap pelaksanaan komunikasi pariwisata yang dilakukan oleh @urangpurwakarta ini dibagi menjadi beberapa bagian konten, yaitu:

- Explore Purwakarta, berisi tentang destinasi wisata dan juga potensi wisata baru. Promosi Taman Air Mancur Sri Baduga masuk dalam kategori ini. Fotofoto yang digunakan pun berasal dari hasil foto tim @urangpurwakarta yang bekerja sama dengan tim dari bidang pariwisata Pemerintah Kabupaten Purwakarta.

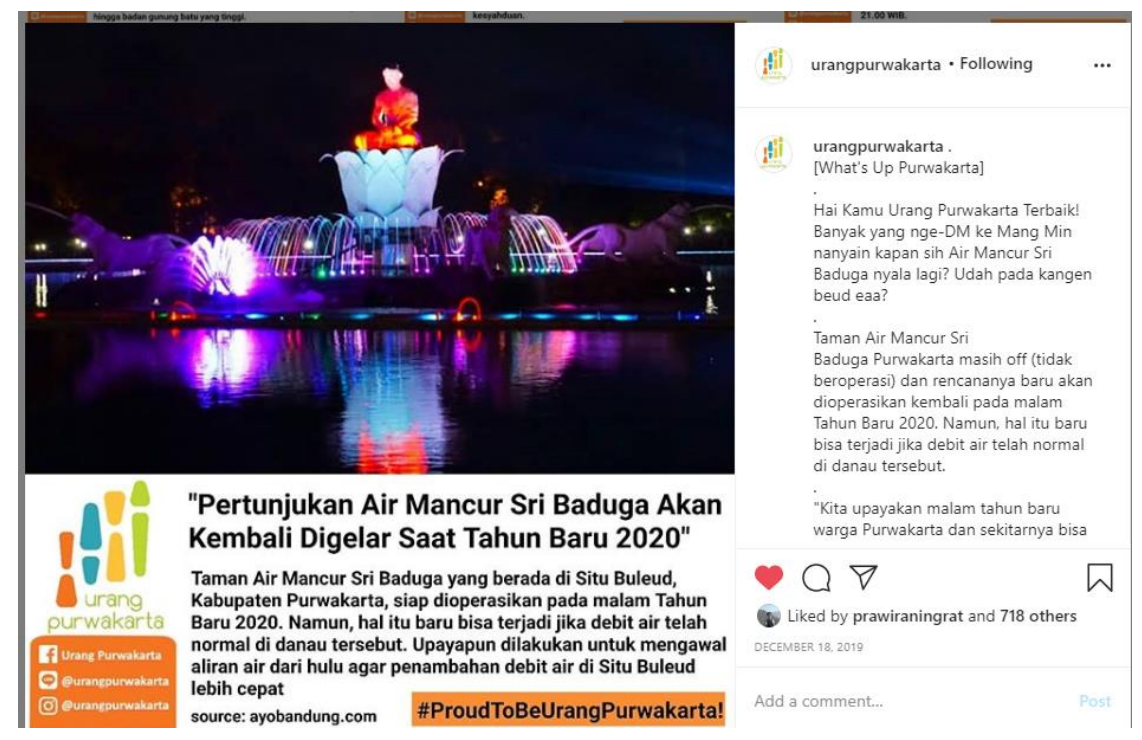

Gambar 2. Unggahan Taman Air Mancur Sri Baduga oleh @urangpurwakarta (Sumber: www.instagram.com/urangpurwakarta diakses pada 4 Juli 2020) 
Dalam unggahan tersebut terlihat bahwa tim @urangpurwakarta senantiasa memberikan informasi penting mengenai operasional Taman Air Mancur Sri Baduga. Setiap malam pergantian tahun baru masehi memang selalu dilakukan berbagai kegiatan terutama di destinasi wisata unggulan, Taman Air Mancur Sri Baduga. Dengan adanya kegiatan yang akan berlangsung, tim @urangpurwakarta pun bergerak cepat untuk memberikan informasi kepada para pengikut Instagram @urangpurwakarta. Dari unggahan tersebut, informasi yang diberikan sangat efektif dengan penggunaan bahasa yang mudah dipahami oleh berbagai kalangan, terutama oleh kalangan muda.

- Asli Purwakarta, merupakan konten kuliner yang disajikan secara informatif tentang kuliner asli atau khas Purwakarta, seperti Sate Maranggi, Soto Sadang, Simping Kaum, dan lain-lain. Kaitannya dengan promosi wisata Taman Air Mancur Sri Baduga ini adalah, mereka menyebutkan bahwa makanan khas Purwakarta tersebut juga hadir di sekitar Taman Air Mancur Sri Baduga. Mengingat bahwa operasional air mancur yang dilaksanakan di akhir pekan, setiap Sabtu Malam di jalan menuju Taman Air Mancur Sri Baduga ini selalu di adakan car free night yang digunakan untuk wisata kuliner para wisatawan yang berkunjung. 


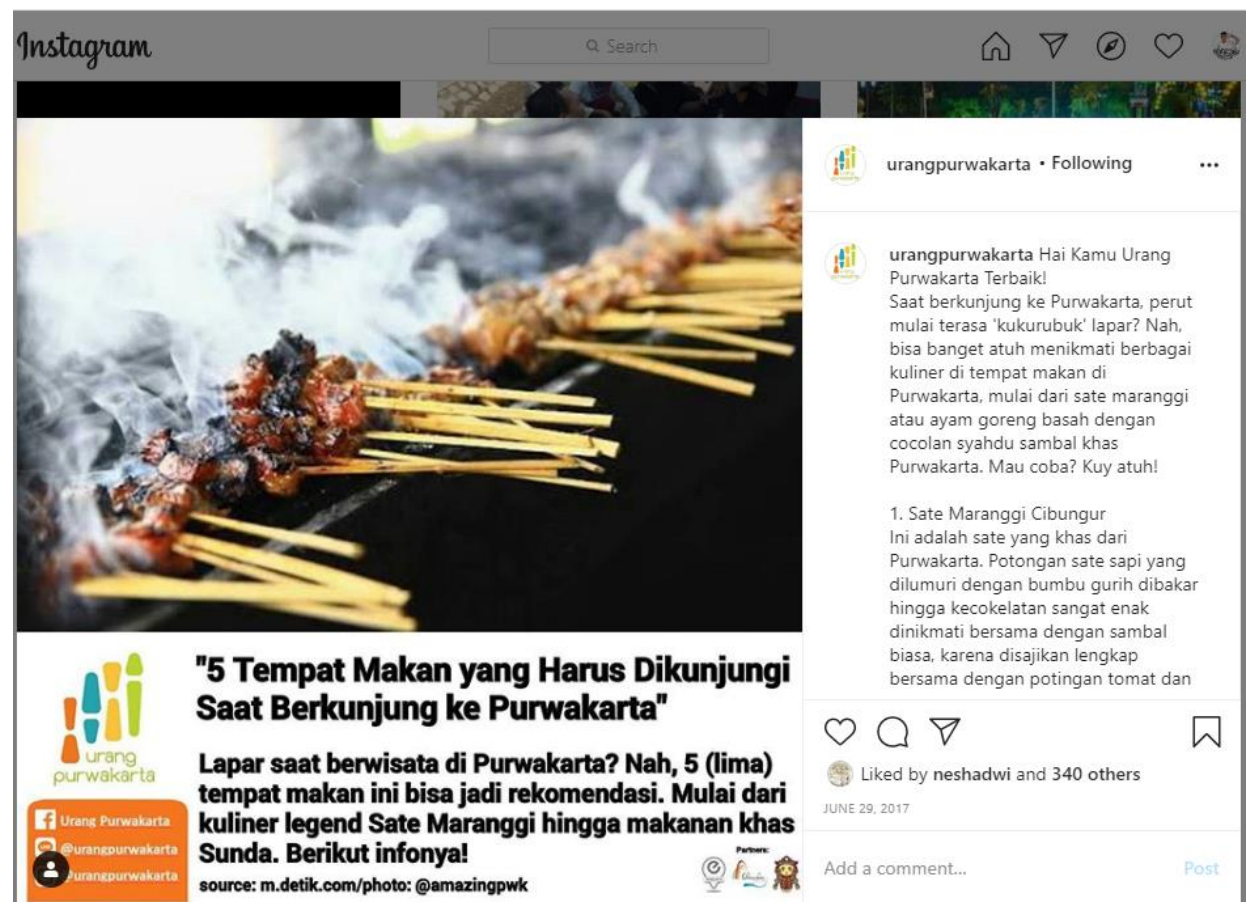

Gambar 3. Unggahan Kuliner Khas Purwakarta

(Sumber: www.instagram.com/urangpurwakarta diakses pada 4 Juli 2020)

Dengan mengunggah konten tersebut, tim dari @urangpurwakarta senantiasa menginformasikan bahwa terdapat pula gerai makanan khas Purwakarta yang berada di sekitar Lokasi Taman Air Mancur Sri Baduga. Sehingga wisatawan tidak perlu repot mencari jauh dimana makanan khas Purwakarta tersebut. Hal ini juga secara tidak langsung menginformasikan bahwa pengunjung Taman Air Mancur Sri Baduga bisa bersantap dengan keluarga sebelum maupun sesudah pertunjukan dimulai.

- Purwakarta Muda, konten berisikan sumber daya manusia asal Purwakarta yang berprestasi dan bisa menjadi inspirasi generasi milenial untuk bisa berkarya dan memiliki kemauan untuk berpendidikan tinggi. Kisah inspiratif dalam mempromosikan Taman Air Mancur Sri Baduga ini muncul dari perancang air mancurnya itu sendiri. Taman Air Mancur Sri Baduga ini dirancang dan dibuat oleh tangan asli Purwakarta, yaitu Kang Hery Sugihardi. Pria lulusan SMK ini mampu membuat sistem air mancur terbesar se-Asia 
Tenggara yang mana air mancur buatannya mampu menari dan berwarna indah. Dari tangannya inilah, Taman Air Mancur Sri Baduga berhasil menjadi Top 5 Destination Pariwisata Indonesia pada tahun 2017.

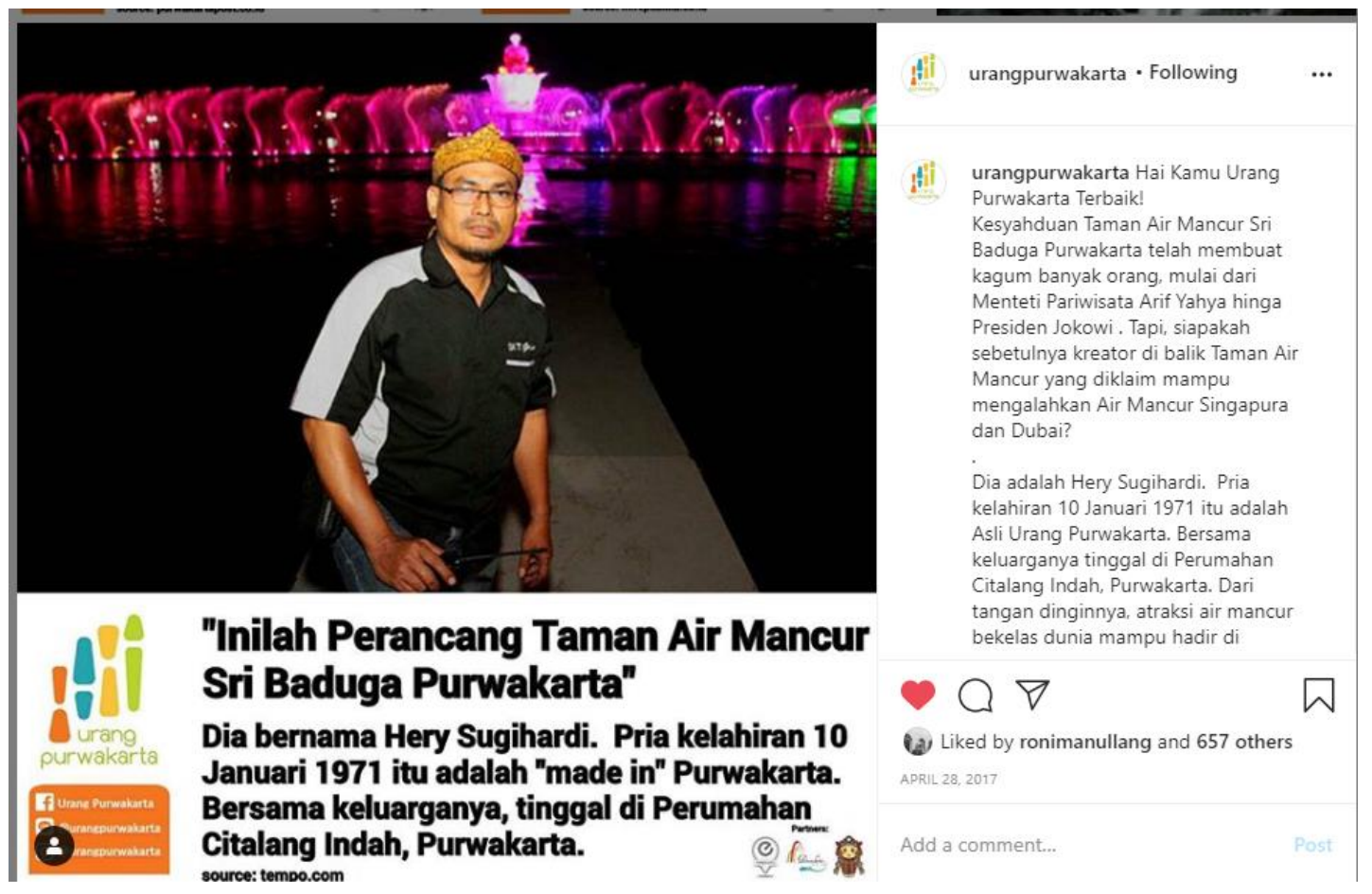

Gambar 4. Unggahan Perancang Taman Air Mancur Sri Baduga yang Merupakan

Orang Asli Purwakarta

(Sumber: www.instagram.com/urangpurwakarta diakses pada 4 Juli 2020)

- What the Facts Purwakarta, konten tentang fakta-fakta menarik termasuk sejarah terkait dengan Purwakarta. Dalam komunikasi pariwisata Taman Air Mancur Sri Baduga ini, tim @urangpurwakarta pun melakukan beberapa fact finding terkait Taman Air Mancur Sri Baduga, Situ Buleud, dan icon apa saja yang terdapat di sekitar Taman Air Mancur Sri Baduga tersebut. 

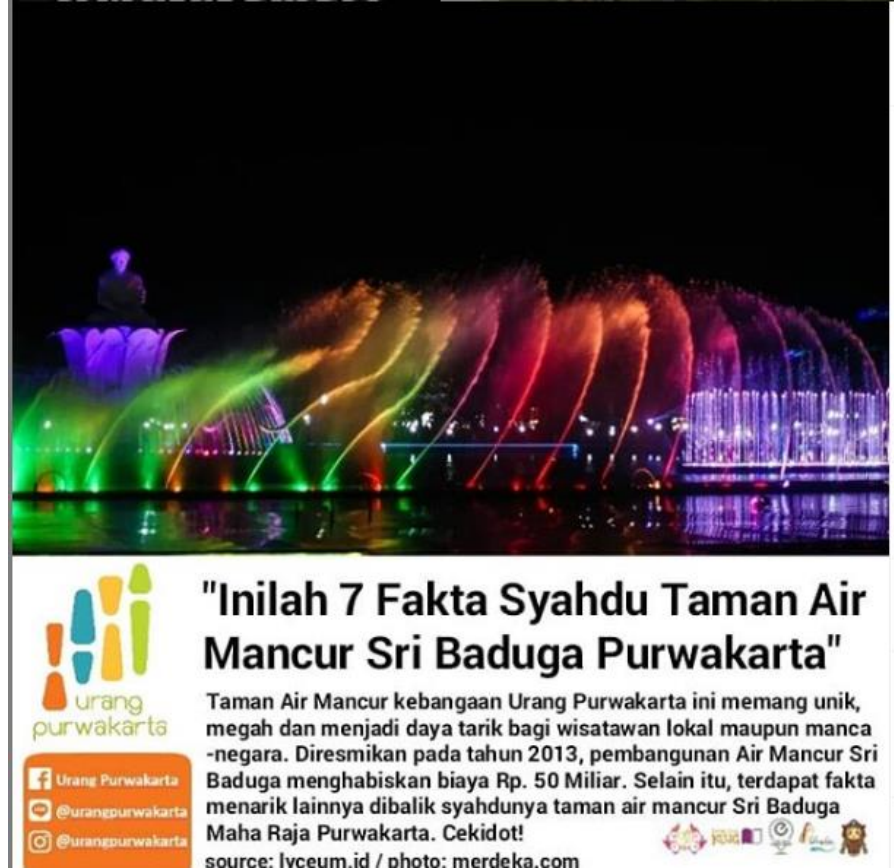

\section{"Inilah 7 Fakta Syahdu Taman Air} Mancur Sri Baduga Purwakarta"

Taman Air Mancur kebangaan Urang Purwakarta ini memang unik, megah dan menjadi daya tarik bagi wisatawan lokal maupun manca -negara. Diresmikan pada tahun 2013, pembangunan Air Mancur Sri Baduga menghabiskan biaya Rp. 50 Miliar. Selain itu, terdapat fakta menarik lainnya dibalik syahdunya taman air mancur Sri Baduga Maha Raja Purwakarta. Cekidot!

source: Ivceum. id / photo: merdeka.com fil urangpurwakarta $\cdot$ Following

aan tempar pangguyangan (pemandian badak). Makanya, ada patung badak sebagai pengingat sejarah.

2. Arsiteknya adalah Asli Urang Purwakarta.

Nama perancang atraksi taman air mancur Sri Baduga adalah Hery Sugihardi. Sosok yang lahir pada Tanggal 10 Januari 1971 Ini adalah asli orang Purwakarta. Beliau bersama keluarganya, tinggal di Perumahan Citalang Indah, Desa Citalang. Purwakarta.

3. Nama Sri Baduga berasal dari Raja Sunda.

Penamaan air mancur ini mengacu pada Sosok patung Sri Baduga yang berdiri meqah di tenqah tengah air

\section{$\bigcirc \bigcirc \nabla$}

Liked by rulquin_ and 1,115 others NEEMBER 9,2018 Add a comment...

Gambar 5. Unggahan 7 Fakta Taman Air Mancur Sri Baduga Purwakarta

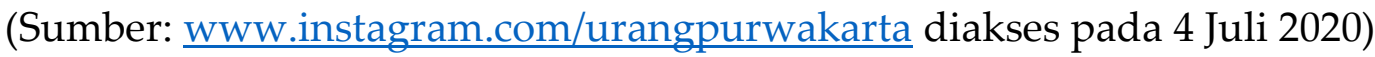

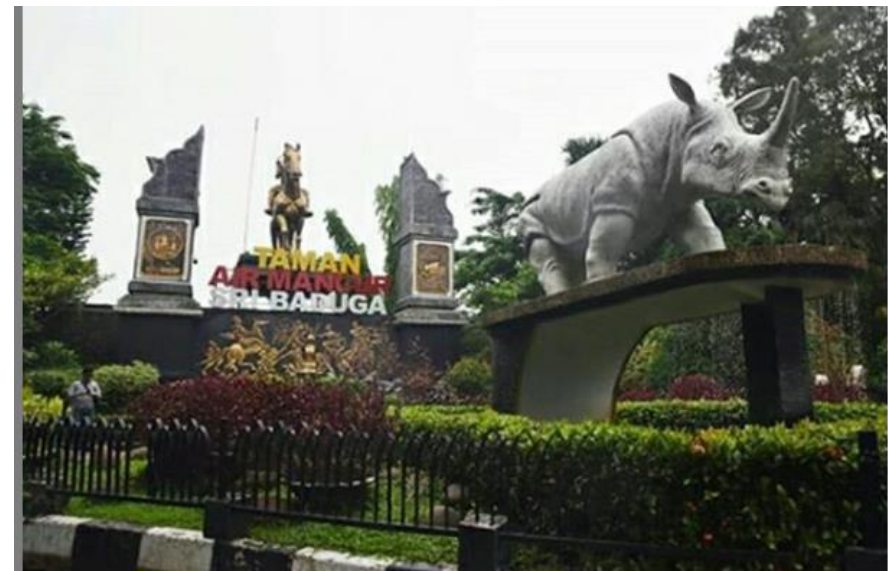

"Kenapa Ada Patung Badak Di Taman Sri Baduga Purwakarta?"

Keberadaan Taman Sri Baduga (Situ Buleud) sudah ada sejak jaman dahulu. Konon, situ atau danau tersebut dulunya merupakan sebuah kubangan besar yang biasa digunakan oleh badak bercula satu seba -gai tempat pangguyangan atau mandi. Sehingga, patung badak ter -sebut sebagai pengingat sejarah Situ Buleud jaman dahulu.

source: m.detik.com / photo: @sunda_sajati \#ProudToBeUrangPurwakarta!
(4) urangpurwakarta - Following ...

urangpurwakarta [WTF Purwakarta]

Hai Kamu Urang Purwakarta Terbaik Suka ada yang bertanya kenapa di Taman Sri Baduga Purwakarta atau Situ Buleud ada patung badak? Padahal kan badak itu identik dengan provinsi Banten?

Nah, ternyata keberadaan patung badak bercula satu yang syahdu ini terkait dengan sejarah Taman Sri Baduga jaman baheula.

Konon situ atau danau tersebut dulunya merupakan sebuah kubangan besar yang biasa digunakan oleh badak bercula satu sebagai tempat

\section{$\bigcirc \bigcirc \nabla$}

W

5 Liked by fajarfa_ and 1,060 others

Gambar 6. Unggahan Fakta Patung Badak di Taman Sri Baduga

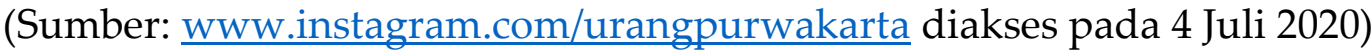




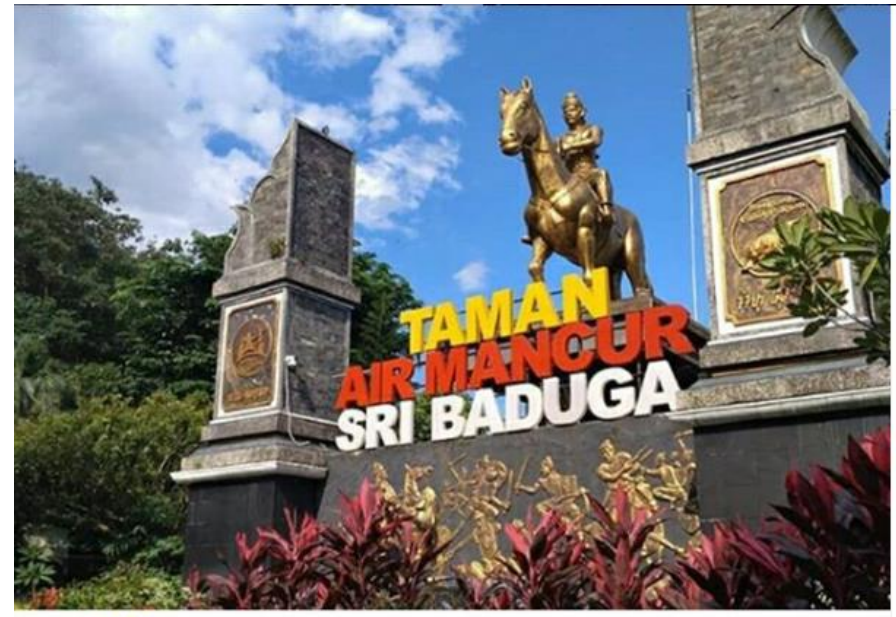

"Mengenal Sosok Sri Baduga, Dibalik Kemegahan Air Mancur Purwakarta"

Sri Baduga atau dikenal sebagai Prabu Siliwangi adalah spiritnya orang Sunda. Sosok yang mengedepankan nilai kasih sayang dan toleransi. Diharapkan penamaan ini sebagi edukasi sejarah kepada masyarakat dan mereprepresentasikan keragaman Indonesia.

source: m.merdeka.com
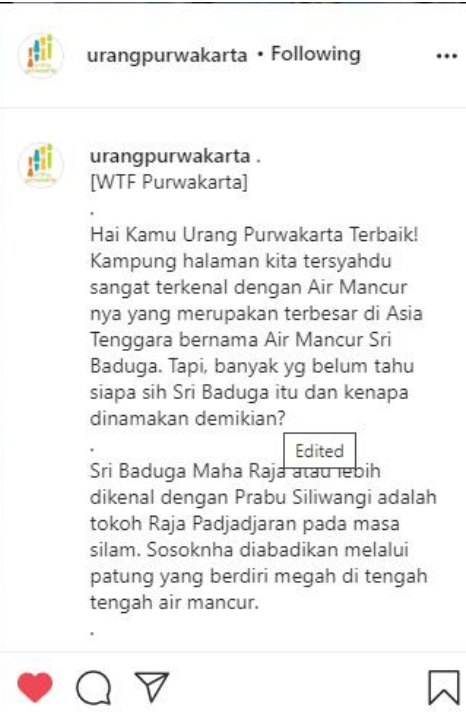

(5) Liked by meizar.r and 1,079 others

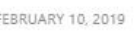

Add a comment...

Gambar 7. Unggahan Fakta Sosok Sri Baduga

(Sumber: www.instagram.com/urangpurwakarta diakses pada 4 Juli 2020)

Uniknya, di setiap unggahan yang dilakukan oleh tim @urangpurwakarta ini selalu menggunakan caption yang khas. Mereka selalu menyapa para pengikutnya dengan sapaan “Hai Kamu Urang Purwakarta Terbaik!”. Hal ini menunjukan kedekatan dan kebanggaan yang diberikan oleh @urangpurwakarta untuk para pengikutnya yang setia mengikuti dan mendapatkan berbagai informasi yang mereka berikan.

Dengan menggunakan sapaan tersebut, peneliti melihat bahwa memang apa yang sudah direncanakan dalam target dilaksanakan dengan baik. Mereka melihat bahwa target dengan rentang usia 15-30 tahun ini harus diberikan afeksi sesuai dengan usianya. Afeksi yang dilakukan yaitu dengan sapaan seperti "Hai Kamu Urang Purwakarta Terbaik!", ada pula sapaan khusus "Kang Bro" untuk pengikut dengan gender laki-laki, dan juga "Teh Sist" untuk pengikut dengan gender perempuan. 
Selain konten khusus tersebut, tim @urangpurwakarta pun membuat dan melaksanakan beberapa kegiatan baik itu yang diinisiasi oleh pihak internal @urangpurwakarta, dari Pemerintah Daerah Kabupaten Purwakarta, maupun pihak eksternal yang ingin mengadakan event besar di lokasi Taman Air Mancur Sri Baduga.

Salah satu kegiatan yang diinisiasi oleh tim @urangpurwakarta adalah Purwakarta Walking Tour. Program ini bertujuan untuk mengenalkan destinasi wisata Purwakarta kepada masyarakat luas melalui media sosial Instagram. Tim @urangpurwakarta mengajak influencer asli Purwakarta dan juga luar Purwakarta untuk berkeliling ke setiap destinasi wisata. Mereka mengharuskan membuat foto dan video terkait dengan destinasi wisata tersebut. Hal ini bertujuan untuk menarik pengikut baru yang berasal dari masing-masing pengikut para influencer tersebut. Dengan demikian, destinasi wisata Purwakarta semakin dikenal oleh berbagai kalangan dari berbagai daerah yang berbeda.

“Kalo misalnya UP untuk ke Sri Baduga kita mulai promosiin Sri Baduga itu di tahun 2016 waktu itu lewat acara Purwakarta Walking Tour. Kita narik influencerinfluencer"(Rifki, 2020).

Selain kegiatan Purwakarta Walking Tour, @urangpurwakarta pun mempromosikan dan selalu menjadi media partner Pemerintah Daerah Kabupaten Purwakarta untuk menginformasikan kegiatan-kegiatan yang ada pada kalender kegiatan Pemkab Purwakarta. Salah satu kegiatan tersebut adalah hiburan pengoperasian Taman Air Mancur Sri Baduga saat malam pergantian tahun baru Masehi. 


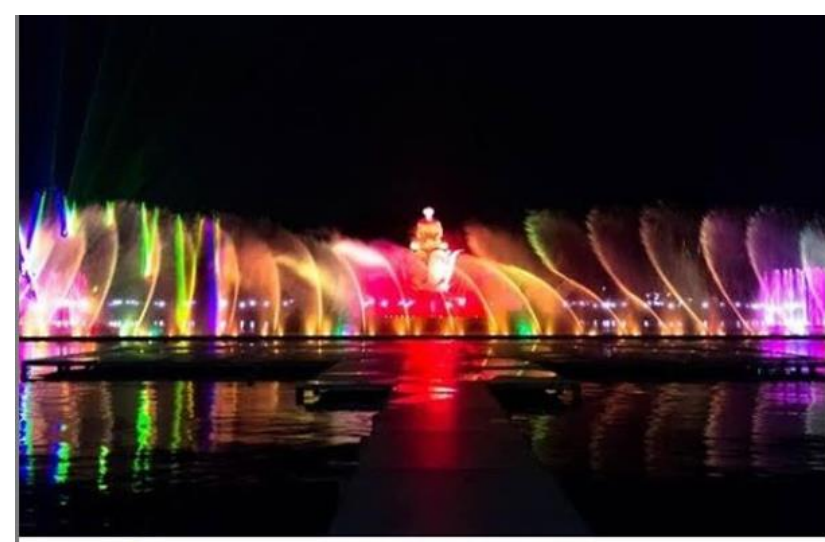

"Air Mancur Sri Baduga dan Festival Budaya Sambut Tahun Baru 2020 di Purwakarta"

Berbagai rangkain acara syahdu direncanakan akan digelar dalam menyambut tahun baru 2020 di Purwakarta, di antaranya yaitu festival musik di Lapang Sahate, festival bambu kultur tradisi di Tajug Gede Cilodong dan kembali dioperasikannya Taman Air Mancur Sri Baduga di Situ Buleud.

source: ayopurwakarta com \#ProudToBeUrangPurwakarta!

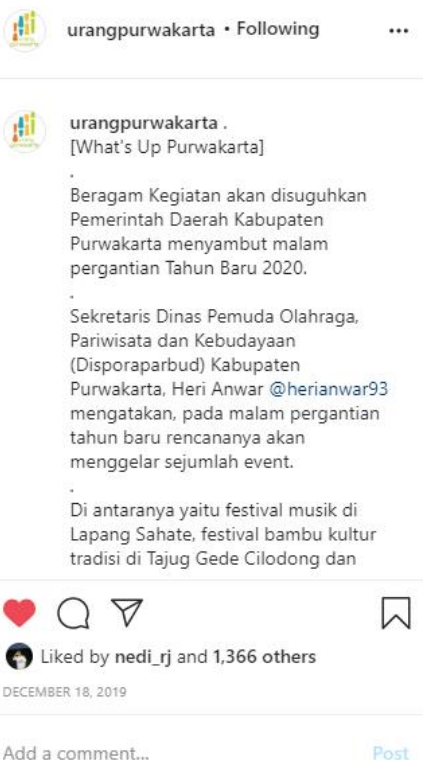

Gambar 8. Unggahan Kegiatan Festival Budaya di Air Mancur Sri Baduga

(Sumber: www.instagram.com/urangpurwakarta diakses pada 4 Juli 2020)

Kegiatan berikutnya adalah kegiatan yang diadakan oleh pihak eksternal yang meminta bantuan media partner kepada @urangpurwakarta. Event tersebut salah satunya adalah Grand Launching Handphone Vivo V15. Dari event ini Taman Air Mancur Sri Baduga disoroti oleh banyak selebriti Indonesia, mereka pun memberikan pujian terhadap pesona keindahan Taman Air Mancur Sri Baduga. Dengan menggunakan lokasi Taman Air Mancur Sri Baduga sebagai venue acara tersebut yang diliput langsung oleh televisi nasional, hal ini meningkatkan popularitas Taman Air Mancur Sri Baduga di tingkat nasional lebih massif lagi. 

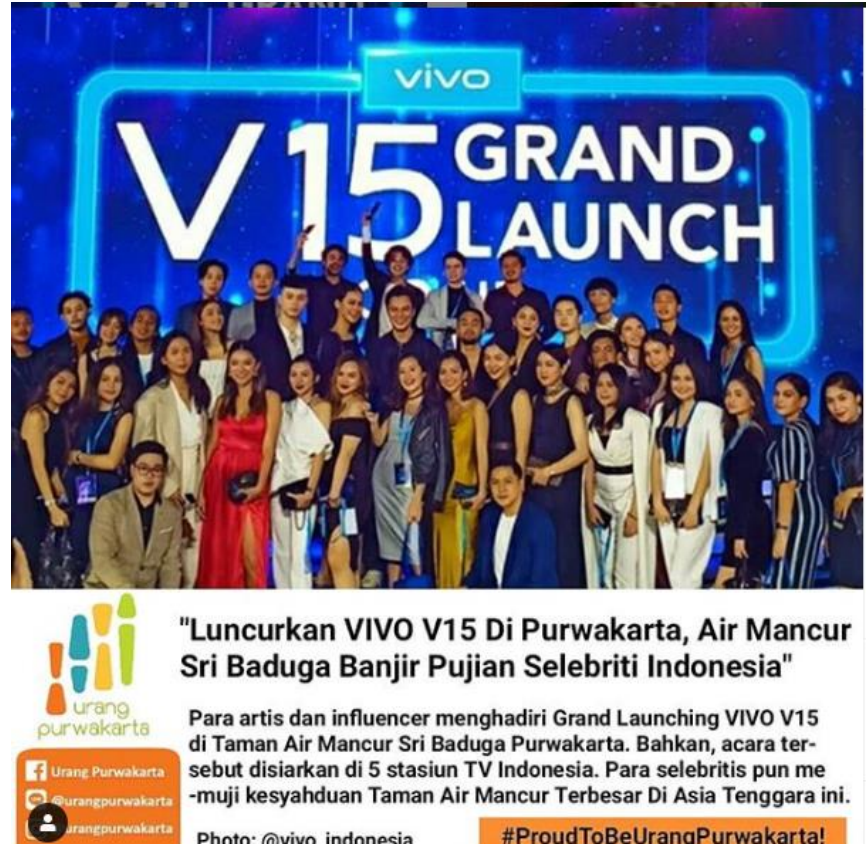

"Luncurkan VIVO V15 Di Purwakarta, Air Mancur Sri Baduga Banjir Pujian Selebriti Indonesia"

Para artis dan influencer menghadiri Grand Launching VIVO V15 di Taman Air Mancur Sri Baduga Purwakarta. Bahkan, acara tersebut disiarkan di 5 stasiun TV Indonesia. Para selebritis pun me

muji disirkan di 5 stasiun TV Indon

Phonto คuivn indonocia

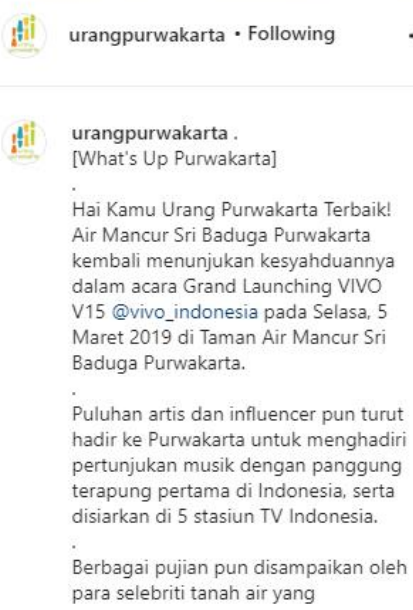

fii urangpurwakarta $\cdot$ Following

urangpurwakarta

[What's Up Purwakarta]

Hai Kamu Urang Purwakarta Terbaik: Air Mancur Sri Baduga Purwakarta kembali menunjukan kesyahduannya dalam acara Grand Launching VIVO V15 @vivo indonesia pada Selasa, 5 Maret 2019 di Taman Air Mancur Sri Baduga Purwakarta.

Puluhan artis dan influencer pun turut hadir ke Purwakarta untuk menghadiri pertunjukan musik dengan panggung terapung pertama di Indonesia, serta disiarkan di 5 stasiun TV Indonesia.

Berbagai pujian pun disampaikan oleh para selebriti tanah air yang

(6) Liked by rulquin_ and 2,755 others

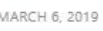

Add a comment...

Gambar 9. Unggahan Kegiatan Grand Launching Vivo V15

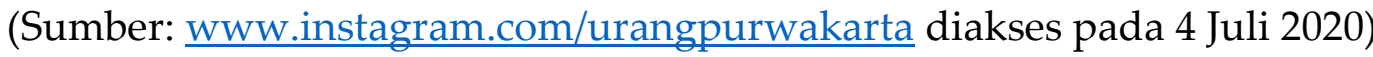

Tabel 2. Tahap Pelaksanaan Komunikasi Pariwisata @urangpurwakarta

\begin{tabular}{|c|c|c|}
\hline No & Perencanaan & \\
\hline 1 & Konten & $\begin{array}{l}\text { - Explore Purwakarta } \\
\text { - Asli Purwakarta } \\
\text { - Purwakarta Muda } \\
\text { - What The Facts Purwakarta }\end{array}$ \\
\hline 2 & Event & $\begin{array}{l}\text { - Purwakarta Walking Tour } \\
\text { - Pelaksanaan Event Tahunan sesuai } \\
\text { kalendar kegiatan Pemkab } \\
\text { Purwakarta } \\
\text { - Pelaksanaan Event Oleh Pihak } \\
\text { Eksternal }\end{array}$ \\
\hline
\end{tabular}




\section{Evaluasi}

Tentunya dalam setiap pelaksanaan kegiatan terdapat beberapa hambatan yang kemudian harus dievaluasi oleh tim pelaksana kegiatan. Dalam hal ini pun terdapat hambatan yang pernah dialami oleh tim @urangpurwakarta. Hambatan tersebut adalah terjadinya missed communication antara akun @urangpurwakarta dengan pengikutnya. Hambatan tersebut berupa tidak tahunya pengunjung Taman Air Mancur Sri Baduga terkait dengan lahan parkir dan juga operasional Taman Air Mancur Sri Baduga. Dengan adanya hambatan tersebut menimbulkan ketidak percayaan pengikut Instagram karena adanya ketidak siapan @urangpurwakarta selaku media promosi dalam memberikan informasi.

Namun hal tersebut tidak lantas menjadikan @urangpurwakarta kehilangan pengikutnya. Mereka mengevalusi kinerja kerja dalam memberikan informasi factual dan actual untuk pengikutnya. Setelah adanya missed communication tersebut, mereka berbenah dan senantiasa memberikan informasi terkait dengan operasional Taman Air Mancur Sri Baduga dan juga guide menuju tempat parkir di sana. Tempat parkir yang tersedia memang masih terbatas dan itu pun dikelola oleh masyarkat bukan oleh pemerintah. Begitupun operasional air mancur yang tidak setiap hari Sabtu-Minggu bisa beroperasi karena melihat debit air dan juga bagaimana kondisi alat.

Kedua hal tersebut sebetulnya lebih kepada hambatan teknis yang notabene pihak penyedia dalam hal ini adalah Pemkab Purwakarta untuk terus meningkatkan kualitas layanan pada destinasi wisata unggulannya. Seperti pada saat ini, Taman Air Mancur Sri Baduga tidak beroperasi karena sedang perbaikan alat yang belum pasti selesainya. Mengingat bahwa masuk untuk menyaksikan air mancur masih gratis, maka pembiayaan pemeliharaan alat pun terbatas. 
Evaluasi yang dilakukan oleh pihak @urangpurwakarta adalah memberikan konten informasi secara cepat, actual dan factual sehingga tidak membuat wisatawan yang mau menyaksikan air mancur tidak perlu dating ke sana untuk mendapatkan informasi. Evaluasi yang dilakukan oleh pihak Pemkab Purwakarta guna bisa mempercepat dan memiliki dana pemeliharaan, akan diberlakukannya uang retribusi untuk masuk menyaksikan air mancur Sri Baduga.
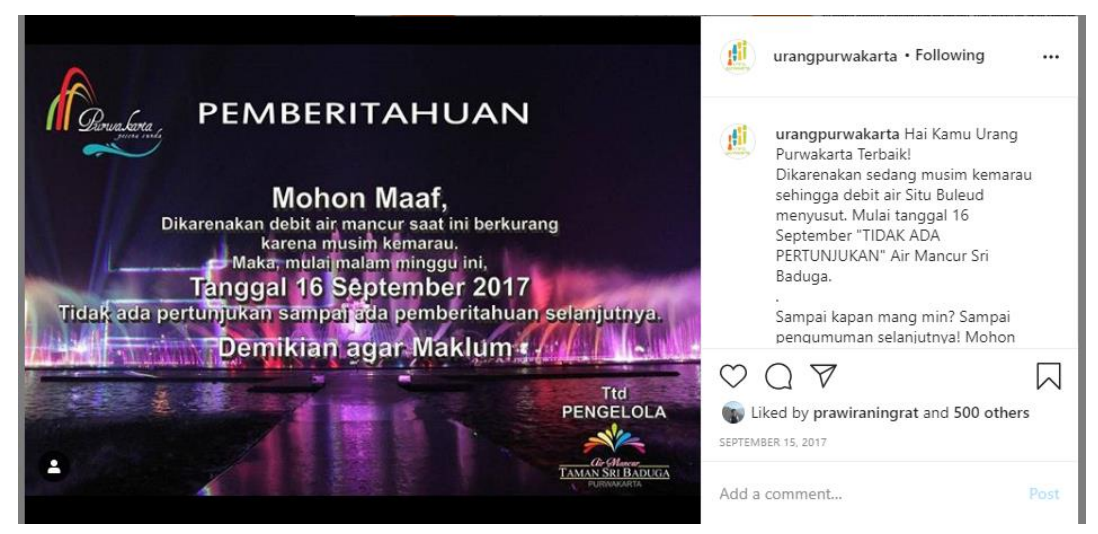

Gambar 10. Unggahan Informasi Pemberitahuan Tidak beroperasinya Taman Air Mancur Sri Baduga

(Sumber: www.instagram.com/urangpurwakarta diakses pada 4 Juli 2020)

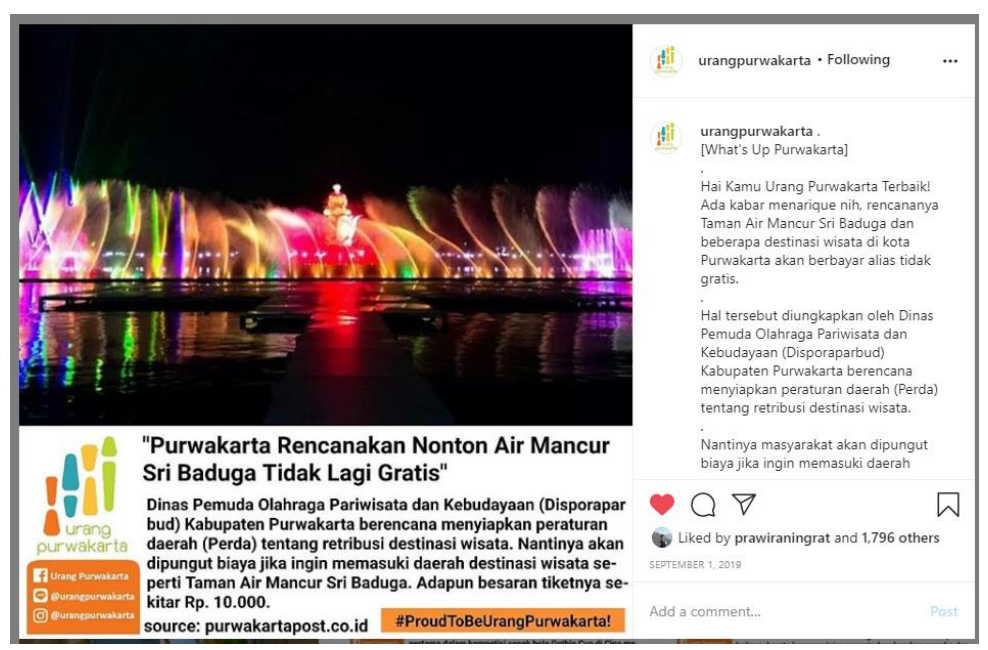

Gambar 11. Unggahan Informasi Akan Berlakunya Tiket Retribusi

Taman Air Mancur Sri Baduga

(Sumber: www.instagram.com/urangpurwakarta diakses pada 4 Juli 2020)

406 JUMPA Volume 7, Nomor 2, Januari 2021 
Stragtegi Komunikasi Pariwisata Taman Air Mancur Sri Baduga melalui Media Instagram...

\section{Kesimpulan}

Strategi komunikasi pariwisata yang dilakukan oleh @urangpurwakarta sudah berjalan sebagaimana mestinya. Mereka membuat beberapa perencanaan, dimulai dari penentuan target, pemilihan media sosial, dan juga konten seperti apa yang akan diinformasikan kepada para pengikut dan calon pengikut media sosial mereka. Tahap kedua adalah pelaksanaan. Dalam pelaksanaannya konten media sosial Instagram @urangpurwakarta pun mengalami perkembangan. Konten tersebut berupa pesan informatif yang terbagi menjadi 4 bagian, yaitu Explore Purwakarta, Asli Purwakarta, Purwakarta Muda, dan What the Facts Purwakarta. Selain konten informatif, pelaksanaan komunikasi pariwisata pun mereka lakukan dengan menjalankan bebegarap program, baik secara internal (@urangpurwakarta dan Pemkab Purwakarta) maupun secara eksternal. Hambatan yang terjadi berupa missed communication seperti tidak diberitahukan akses parkir di Taman Air Mancur Sri Baduga, dan juga jadwal operasional air mancur itu sendiri yang membuat wisatawan kecewa. Dengan adanya hambatan tersebut, @urangpurwakarta pun melakukan evaluasi dan menjadi lebih aktif dalam memberikan informasi sesuai arahan dari pengelola Taman Air Mancur Sri Baduga Purwakarta.

\section{Daftar Pustaka}

Arifin, Z. (2012). Penelitian Pendidikan dan Paradigma Baru. PT. Remaja Rosdakarya. Desrianto, M. (2019, July 4). Menpar Sumringah Posisi Indonesia di Peringkat Pariwisata Dunia Naik. Travel.Kompas.Com. https://ravel.kompas.com/read/2019/09/06/114334127/menpar-sumringahposisi-indonesia-di-peringkat-pariwisata-dunia-naik?page=all

Effendy, O. U. (1993). Ilmu, Teori, dan Filsafat Komunikasi. PT. Remaja Rosdakarya. 
Fatanti, M. N., \& Suyadnya, I. W. (2015). Beyond User Gaze: How Instagram Creates Tourism Destination Brand? Procedia - Social and Behavioral Sciences, 211(September), 1089-1095. https://doi.org/10.1016/j.sbspro.2015.11.145

Gohil, N. (2015). Role and Impact of Social Media in Tourism : A Case Study on the Initiatives of Madhya Pradesh State Tourism INTRODUCTION : REVIEW OF LITERATURE : 5(4), 8-15.

Hadari, N. (2003). Metode Penelitian Bidang Sosial. Gajah Mada Press.

Irfan. (2020). Wawancara Dengan Kabid Pariwisata.

Littlemore, J. (2003). The Communicative Effectiveness of Different Types of Communication Strategy.

Moleong, L. (2005). Metodologi Penelitian Kualitatif. PT. Remaja Rosdakarya.

Nugraha, A. M. (2018). Air Mancur Terbesar di Asia Tenggara, Ada di Purwakarta. Travel.Detik.Com. https://travel.detik.com/dtravelers_stories/u-4126899/airmancur-terbesar-di-asia-tenggara-ada-di-purwakarta

Prawiraningrat, A. (2020). Wawancara dengan Pendiri @urangpurwakarta.

Purwakarta, P. (2018). Sejarah Taman Sri Baduga. https://purwakartakab.go.id/read/129\#: :text=Sebelum menjadi taman sri baduga,kota Purwakarta pada tahap awal.

Rifki, M. (2020). Wawancara dengan Kepala Divisi Program and Event @urangpurwakarta.

Usman, H. (2009). Metode Penelitian Sosial. Bumi Aksara.

www.instagram.com/urangpurwakarta diakses pada 4 Juli 2020

408 JUMPA Volume 7, Nomor 2, Januari 2021 
Stragtegi Komunikasi Pariwisata Taman Air Mancur Sri Baduga melalui Media Instagram...

\section{Profil Penulis}

Gheya Madinatu Sjaida. Meraih gelar Sarjana Ilmu Perpustakaan di bidang Fakultas Ilmu Komunikasi pada tahun 2018 dan sedang menyelesaikan pendidikan jenjang pascasarjana S2 di Program Magister Pariwisata Berkelanjutan di Universitas Padjadjaran. Telah menulis pada Jurnal Tornare yang merupakan Jurnal Pariwisata Indonesia Berkelanjutan dengan fokus khusus pada studi pariwisata Indonesia. Dan saat ini ia bekerja sebagai pegawai pemerintah di Dewan Perwakilan Daerah Republik Indonesia.

Ute Lies Khodijah. Meraih gelar Doktor pada bidang Komunikasi di Pascasarjana Ilmu Perpustakaan Universitas Padjadjaran Bandung pada tahun 2016. Ia menyelesaikan pendidikan jenjang pascasarjana S2 di Program Magister Ilmu Sosial di Universitas Padjadjaran pada tahun 2005 dan program Sarjana dari jurusan Fakultas Ilmu Komunikasi Tahun 1999. Saat ini ia merupakan pengampu Program Studi Magister Pariwisata Berkelanjutan di Universitas Padjajaran untuk mata kuliah seperti Pariwisata Cultural dan Heritage dan Metode Penelitian Pariwisata. Telah menulis pada Manajemen Strategis Dalam Pengembangan Program Konsorsium EJournal oleh FPPTI Jawa Barat, dan Literasi Sosial Budaya Masyarakat Penyangga Hutan Terhadap Pelestarian Taman Nasional Gunung Gede Halimun Salak (TNGHS). Untuk jabatan akademik ia menjabat sebagai Kepala Unit Internasionalisasi Sekolah Pasca Sarjana Universitas Padjajaran sampai sekarang.

Evi Novianti. Meraih gelar Doktor pada bidang Komunikasi dan Budaya di Program Pascasarjana Ilmu Komunikasi Universitas Padjadjaran Bandung pada tahun 2012. Ia menyelesaikan pendidikan jenjang pascasarjana S2 di Program Magister Ilmu Komunikasi di Universitas Padjadjaran pada tahun 2001 dan program Sarjana dari jurusan Ilmu Hubungan Masyarakat Fakultas Ilmu Komunikasi Tahun 1995. Saat ini ia merupakan pengampu di Fakultas Ilmu Komunikasi Unpad Program Pascasarjana 
(S2) dan Program Studi Ilmu Hubungan Masyarakat, untuk matakuliah seperti Komunikasi Lintas Budaya, Komunikasi Massa, Pengantar Public Relations, Audit Humas, Periklanan, Kapita Selekta Humas dan Teori Komunikasi. Telah menulis buku. Pola Komunikasi Perkawinan Antar Budaya tahun 2013. Telah menulis pada International Journal of Sosial Sciences. Menulis buku Teori Komunikasi pada tahun 2015 serta buku Bisnis Lintas Budaya di tahun yang sama. Untuk jabatan akademik menjabat sebagai Sekertaris Program Magister Ilmu Komunikasi 2016-2018, dan Ketua Program Studi Magister Pariwisata Berkelanjutan Universitas Padjajaran 2018sekarang. 